\title{
Derivation, characterization, and in vitro cell regeneration of canine white adipose tissue-derived mesenchymal stem cells obtained from a mesenteric region
}

\author{
Anirban Mandal ${ }^{1,2^{*}}$ (D) Ajeet Kumar $\mathrm{Jha}^{3}$, Dew Biswas ${ }^{4}$ and Shyamal Kanti Guha ${ }^{1 *}$
}

\begin{abstract}
Background: The study was conducted to assess the characterization, differentiation, and in vitro cell regeneration potential of canine mesenteric white adipose tissue-derived mesenchymal stem cells (AD-MSCs). The tissue was harvested through surgical incision and digested with collagenase to obtain a stromal vascular fraction. Mesenchymal stem cells isolated from the stromal vascular fraction were characterized through flow cytometry and reverse transcription-polymerase chain reaction. Assessment of cell viability, in vitro cell regeneration, and cell senescence were carried out through MTT assay, wound healing assay, and $\beta$-galactosidase assay, respectively. To ascertain the trilineage differentiation potential, MSCs were stained with alizarin red for osteocytes, alcian blue for chondrocytes, and oil o red for adipocytes. In addition, differentiated cells were characterized through a reverse transcription-polymerase chain reaction.

Results: We observed the elongated, spindle-shaped, and fibroblast-like appearance of cells after $72 \mathrm{~h}$ of initial culture. Flow cytometry results showed positive expression for CD44, CD90, and negative expression for CD45 surface markers. Population doubling time was found $18-24 \mathrm{~h}$ for up to the fourth passage and $30 \pm 0.5 \mathrm{~h}$ for the fifth passage. A wound-healing assay was used to determine cell migration rate which was found $136.9 \pm 4.7 \mu \mathrm{m} / \mathrm{h}$. We observed long-term in vitro cell proliferation resulted in MSC senescence. Furthermore, we also found that the isolated cells were capable of differentiating into osteogenic, chondrogenic, and adipogenic lineages.

Conclusions: Mesenteric white adipose tissue was found to be a potential source for isolation, characterization, and differentiation of MSCs. This study might be helpful for resolving the problems regarding the paucity of information concerning the basic biology of stem cells. The large-scale use of AD-MSCs might be a remedial measure in regenerative medicine.
\end{abstract}

Keywords: Canine mesenteric white adipose tissue-derived mesenchymal stem cells, Stromal vascular fraction, Cell regeneration, Wound healing assay, Trilineage differentiation

\footnotetext{
*Correspondence: anirbanmondal31@gmail.com; drskguha2004@yahoo.co.in

'Stem Cell Laboratory, Department of Veterinary Clinical Complex, West Bengal University of Animal and Fishery Sciences, Kolkata 700037, India Full list of author information is available at the end of the article
}

(c) The Author(s). 2021 Open Access This article is licensed under a Creative Commons Attribution 4.0 International License, which permits use, sharing, adaptation, distribution and reproduction in any medium or format, as long as you give appropriate credit to the original author(s) and the source, provide a link to the Creative Commons licence, and indicate if changes were made. The images or other third party material in this article are included in the article's Creative Commons licence, unless indicated otherwise in a credit line to the material. If material is not included in the article's Creative Commons licence and your intended use is not permitted by statutory regulation or exceeds the permitted use, you will need to obtain permission directly from the copyright holder. To view a copy of this licence, visit http://creativecommons.org/licenses/by/4.0/. 


\section{Background}

Mesenchymal stem cells (MSCs) are the promising entities in cell-based research as gripping the distinctive property of differential plasticity as well as self-renewal capability. Canine adipose tissue, a specialized type of connective tissue derived from embryonic mesenchyme, is a foremost source of MSCs owing to its abundance $\left(3.5 \times 10^{4} \mathrm{~g}^{-1}\right)$ and easy accessibility plus negligible donor site demolition (Mester, Opincariu, Benedek, \& Benedek, 2018; Özen, Gül Sancak, Ceylan, \& Özgenç, 2016). MSCs are predominantly the adult stem cells with a significant tissue repairing proficiency characterized by their inclination for cell-to-cell contact and selfproliferation (Chen, Zhou, \& Pan, 2014; Tan et al., 2019). It was reported that adipose tissue-derived MSCs possess the ability to differentiate into osteocytes, chondrocytes, myocytes, and reverse to adipocytes, depending on the specific cell culture conditions (Kim, 2014). As osteocytes and chondrocytes are the essential prerequisites for bone development and cartilage formation, their prolonged expansion may be utilized in such critical wound cases where the normal recovery process fails to rejuvenate and surgery is also too hard to be done (Kriston-Pál et al., 2017). Yaneselli et al. (2018) reported that adipose tissue-derived mesenchymal stem cells preserve multi-potentiality during a higher number of passages with possessing significantly greater osteogenic potential compared to other sources of canine tissue-derived stem cells. Therefore, canine AD-MSCs may bring a new hope in the field of regenerative medicine by representing the unique differential potentials.

The functional potential of MSCs is known to decline with age, a process called senescence. Distinguishing nature of the senescence phenotype of MSCs includes growth arrest, loss of dividing capability, enlarged or flattened morphology, extracellular matrix degeneration together with increased expression of senescenceassociated $\beta$-galactosidase, and surface marker alteration (Van Deursen, 2014). For the in vitro studies, canine adipose tissue-derived MSCs can be maintained for a longer period with stable population doubling and lower rate of senescence (Brandalise et al., 2010). MSCs are quiescent, live precursors responsible for replenishing cell deficits in healing wounds through renewing, replacement, and regeneration processes (Chagastelles \& Nardi, 2011). Responding to the local developmental cues, the regeneration process mediates functional recovery of tissue injury to maintain the normal structural continuity (Facchin et al., 2018). It is a complex cellular event where early signals stimulate the production of new cells to rebuild the lost structures and subsequent signaling regulates the regrowth and patterning of newly formed ones (King \& Newmark, 2012). Researchers are interested in finding direct transplantation strategies by availing those remarkable features of MSCs which might be prospective in advanced translational biology.

A very little evidence of MSC clinical application is available in the canine model due to insufficient information regarding canine stem cell basics. In this context, we have carried out some in vitro experiments to analyze some cytological attributes of canine AD-MSCs. Therefore, the main goals of our study involve isolation, culture, and maintenance of canine white adipose tissuederived MSCs with the differentiation and confirmatory characterization of respective cell types by evaluating major gene expression. This is a foundational step for using stem cells in orthopedic therapy.

\section{Methods}

\section{Isolation and culture of canine white adipose tissue}

Total 5 donor dogs were selected for collection of adipose tissue based on the history of satisfactory health status, no recent medication, proper vaccination, and owners' harmony and informed consent were written. All the experiments were conducted after receiving the approval from Committee for the purpose of control and supervision of experiments on animals (CPCSEA), Government of India. A small surgical incision $(\sim 4 \mathrm{~cm})$ was made aseptically in dog's abdomen after injecting diazepam $\left(0.5 \mathrm{mg} \mathrm{kg}^{-1}\right)$ intravenously. About $5 \mathrm{~g}$ of the white adipose tissue from the mesenteric region was collected in a falcon tube containing DPBS (Sigma, USA). The collected adipose tissue sample was washed with DPBS repeatedly to remove the blood cells and then minced finely (1-2 $\mathrm{mm}$ in size) with a surgical scalpel inside the biosafety cabinet. The sample was digested with collagenase (Sigma, USA). Three different concentrations of collagenase were used with varying incubation periods: (a) $100 \mu \mathrm{g} \mathrm{ml}^{-1}$ overnight, (b) $500 \mu \mathrm{g} \mathrm{ml}^{-1}$ for $60 \mathrm{~min}$, and (c) $250 \mu \mathrm{g} \mathrm{ml}^{-1}$ for $60 \mathrm{~min}$. The whole process of digestion was carried out at $37^{\circ} \mathrm{C}$ temperature. The digested cells were filtered through a $70-\mu \mathrm{m}$ cell strainer (Corning, USA) and centrifuged at $2000 \times g$ for $5 \mathrm{~min}$. Cells were grown in T25 flasks in a humidified incubator at $37^{\circ} \mathrm{C}$ in $5 \% \mathrm{CO}_{2}$. Every 72 -h interval, cells were refed with fresh DMEM-LG medium containing 20\% FBS (Thermo Fisher Scientific, USA, Cat no: 16000044). Microscopic observations were done at every 24-h interval to ensure cell confluency.

\section{Characterization of MSCs Immunophenotyping}

Flow cytometry analysis was done to evaluate the expression of stem cell surface marker proteins. CD44 and CD90 were selected as positive markers and CD45 as a negative marker. After a second passage, cells were trypsinized, centrifuged, and resuspended in DPBS at a concentration of about $5 \times 10^{5}$ cells/tube for each test. Cells 
were incubated with FITC or PE-conjugated antibodies against CD44 (11-5440-42, eBioscience, USA.), CD90 (12-5900-41, eBiosciences, USA), and CD45 (11-545041, eBioscience, USA) for $45 \mathrm{~min}$ at room temperature in the dark. After washing, cells were resuspended in fresh DPBS and ten thousand events were acquired using BD FACSCalibur flow cytometer (BD Biosciences, USA). In all experiments, negative controls (that were stained without antibodies) and isotype controls (rat IgG1 K isotype control FITC for CD 44, 11-4321-80; eBioscience, USA, rat IgG $2 \mathrm{~b} \mathrm{~K}$ isotype control PE for CD 90, 12-4031-82; eBioscience, USA and rat IgG 2b K isotype control FITC for CD45, 11-4031-82; eBioscience, USA) were kept for references. BD CellQuest Pro software was used for flow cytometric data analysis.

\section{$R T-P C R$}

The total RNA extraction was done from well-grown cells using TRIzol reagent (Ambion, USA) following the manufacturer's guidelines. Then, $2 \mu \mathrm{g}$ of RNA was subjected to cDNA synthesis using RevertAid reverse transcriptase (Thermo Fisher Scientific, USA) in a thermocycler (HiMedia Laboratories, India) as per the manufacturer's protocol. Twenty microliters of PCR reaction mixture was prepared with $2 \mu \mathrm{l}$ of cDNA, $0.5 \mu \mathrm{M}$ of forward and reverse primers, $200 \mu \mathrm{M}$ of dNTPs, and $1.25 \mathrm{U}$ of Taq polymerase. Individual PCR was performed for CD45, CD73, CD90, and CD105 to evaluate the expression of different surface markers, and GAPDH was selected as control. PCR was done also for three pluripotency markers viz., Oct4, Nanog, and Sox2. PCR profile set for each of the 30 cycles was the following: $95^{\circ} \mathrm{C}$ (melting temperature) for 5 $\mathrm{min}, 95^{\circ} \mathrm{C}$ for $30 \mathrm{~s}, 58-60^{\circ} \mathrm{C}$ (annealing temperature) for $30 \mathrm{~s}, 72^{\circ} \mathrm{C}$ (extension temperature) for $30 \mathrm{~s}$ followed by $72^{\circ} \mathrm{C}$ for $5 \mathrm{~min}$. The PCR products were resolved by electrophoresis in $1.8 \%(\mathrm{w} / \mathrm{v})$ agarose gel stained with ethidium bromide, and images were captured by the Chemidoc XRS system (Bio-Rad, USA) (Table 1).

\section{Measurement of population doubling time}

Population doubling time was measured to assess the cell growth in different passages. The time of population doublings was calculated using the formulae: $\mathrm{DT}=\mathrm{T} \mathrm{X}$ $\log 2 / \log \left(\mathrm{N}_{\mathrm{t}} / \mathrm{N}_{0}\right)$, where $\mathrm{T}$ is the incubation time in any unit, $N_{0}$ is the cell number at the beginning of the incubation time, $N_{\mathrm{t}}$ is the cell number at the end of the incubation time (Greenwood et al., 2004). Doubling time (DT) was determined in cultures till passage 5 .

\section{Measurement of cell proliferation}

Cell proliferation was measured by MTT [3-(4,5-dimethylthiazol-2-yl)-2,5-diphenyltetrazolium bromide] assay (Mosmann, 1983). Cells $\left(5 \times 10^{3} /\right.$ well) seeded on a 96 well plate were grown for $72 \mathrm{~h}$ at $37^{\circ} \mathrm{C}$ and then supplemented with 20 $\mu \mathrm{l}$ of MTT reagent $\left(5 \mathrm{mg} \mathrm{ml}^{-1}\right.$ ) (HiMedia Laboratories, India). After $4 \mathrm{~h}$ of incubation, formazan crystals were formed. These crystals were dissolved with $100 \mu \mathrm{l}$ of solubilization buffer (10 \% SDS in $0.01 \mathrm{M} \mathrm{HCl})$, and absorbance was measured at $590 \mathrm{~nm}$ with a reference wavelength of $650 \mathrm{~nm}$ using a microplate reader (Bio-Rad, USA).

\section{Wound healing assay}

From a completely confluent culture ( $90 \%)$, monolayer cells were scraped with the help of a pipette tip to create a scratch of uniform width. Cell migration was assessed by capturing images using phase-contrast microscope at different times till wound closure. The migration rate of cells was calculated by measuring the distance between

Table 1 Primers for the detection of mesenchymal stem cells markers

\begin{tabular}{lll}
\hline Primer & Forward & Reverse \\
\hline CD45 & GGCAAACATGTGAGGACAGA & TCCAGATCAAAATTCCACGA \\
CD73 & CCAGCAGTTGAAGGTCGAT & CCATCACCAAGCCAGTTCCT \\
CD90 & CGTGATCTATGGCACTGTGG & TATGCCCTCACACTTGACCA \\
CD105 & AAAACAGACTCACCCAGCCC & TGGGGTCTCCATGTGACAGT \\
NANOG & GGTGTCCTACAGCAATCCAC & CAGCCAACGCTACTGAAACC \\
OCT4 & GAGTGAGAGGCAACCTGGAG & GTGAAGTGAGGGCTCCCATA \\
SOX2 & AGTCTCCAAGCGACGAAAAA & GCAAGAAGCCTCTCCTTGAA \\
Osteopontin & TGAAAAGTGCGAGTATGGAA & TCAGAATTTCCTGGCTACC \\
COL1A1 & GAGAGAGGTGAACAAGGTC & ACCCTTAGCACCATCATTG \\
Aggrecan & GGCATTGTGTTCCATTACAG & CTCATCCTTGTCTCCATAGC \\
SOX9 & AACGCCTTCATGGTGTG & GTACTTGTAATCCGGGTGG \\
Leptin & TGACGACTGTTACTGGGGC & GTTGGGTGAGCCAGTCAGA \\
FABP4 & TGTGCTGGATCTTCTTACTCA & GGTATGAAGTGGCAGGGCTT \\
GAPDH & AACATCATCCCTGCTTCCAC & GACCACCTGGTCCTCAGTGT \\
\hline
\end{tabular}


the two edges of the scratch dividing by the time interval. Measurement was done at five different points for each scratch (Himal, Goyal, \& Ta, 2017).

\section{Senescence cell detection}

Microscopic observation was performed to study the occurrence of senescence-specific morphological changes. For detection of typical signs of senescence, $\beta$ galactosidase assay was performed using the Senescence Cells Histochemical Staining Kit (Cat no: CS0030), Sigma, USA. Two types of media were used for cell growth viz., DMEM-HG+ 10\% FBS and DMEM-LG+ $20 \%$ FBS for the comparative study. The growth medium of the respective cells was aspirated and cells were washed with DPBS twice. Fixation buffer was then added and cells were incubated at room temperature for 6-7 min. After fixation, cells were rinsed with DPBS thrice and incubated with $1 \mathrm{ml}$ of staining solution overnight at $37^{\circ} \mathrm{C}$. Blue-colored cells were observed under a microscope for the detection of cells positive for $\beta$ galactosidase activity.

\section{Trilineage differentiation}

Specific basal medium with respective supplement (9:1) was used for preparing three differential media (osteogenic, chondrogenic, and adipogenic) following manufacturer's protocol (Thermo Fisher Scientific, USA). Cells were grown 14 days for chondrogenesis and 21 days for osteogenesis and adipogenesis with every $48 \mathrm{~h}$ of media change. For the morphological study, cells were observed under a phase-contrast microscope.

In case of osteogenesis, alizarin red S (Sigma, USA) staining was carried out to detect calcified extracellular matrix deposits (Zajdel, Kałucka, Kokoszka-mikołaj, \& Wilczok, 2017). Before cell staining, culture media were discarded and cells were washed with DPBS, followed by fixation with formaldehyde (4\%). Then, the cells were rinsed with sterile distilled water and stained with $0.5 \%$ alizarin red $\mathrm{S}(\mathrm{w} / \mathrm{v}$ in water; $\mathrm{pH} 4.1-4.3)$ for $8-10 \mathrm{~min}$ at room temperature and observed under a phase-contrast microscope. For chondrogenesis, micromasses were stained with Alcian blue (Sigma, USA) for the confirmation of sulfated proteoglycan-rich matrix (Ogawa et al., 2004). After fixation, cells were incubated with Alcian blue (1\%) staining solution for $30 \mathrm{~min}$. Then, cells were washed with $0.1 \mathrm{~N} \mathrm{HCl}$ followed by rinsing with sterile distilled water and observed under phase-contrast microscope. Similarly, oil red O (Sigma, USA) staining was done to examine the lipid droplet formation for the determination of adipogenesis (Neupane, Kiupel, \& Yuzbasiyan-gurkan, 2008). After fixation, oil red O (5 $\mathrm{mg} \mathrm{ml}^{-1}$ ) staining solution was diluted (stock: water $=2$ : 3 ) and the cell was incubated in staining solution for 30 min. The cells were then washed with sterile distilled water to remove excess stain and observed under a microscope.

Differentiated cells were characterized through RTPCR as described earlier. Expression of osteopontin and collagen I was assessed for detection of osteogenic differentiation. Likewise, aggrecan and Sox9 expression were examined for validating chondrocytes. Similarly, expression of FABP4 and leptin was evaluated in both differentiated and undifferentiated cells for confirmation of adipogenic differentiation. GAPDH was used as a loading control.

\section{Statistical analysis}

Statistical analysis was assessed by Student's $t$ test. All $P$ values were derived from a two-tailed statistical test using the SPSS software (version 22.0.0.0). A value of $P$ $<0.05$ was considered statistically significant.

\section{Results \\ Establishment of canine white adipose tissue-derived primary culture for MSCs}

Mesenteric white adipose tissue was collected aseptically from the operating theater during surgery. The tissue was excised with sterilized scissors and immersed in DPBS. It was then transported to the stem cell laboratory of the West Bengal University of Animal and Fishery Sciences (WBUAFS) for MSCs culture (Fig. 1). The minced tissue was digested in three different ways, among which $250 \mu \mathrm{g} \mathrm{ml}^{-1}$ collagenase used for tissue digestion in a 60-min incubation showed the highest efficiency in terms of the number of attached cells followed by $500 \mu \mathrm{g} \mathrm{ml}^{-1}$ for $60 \mathrm{~min}$ and $100 \mu \mathrm{g} \mathrm{ml}^{-1}$ for overnight (data not shown). We found that under suitable growth conditions, cells reached approximately $30-80 \%$ confluency from 3 to 6 days of incubation (Fig. 2a-d). The bar diagram also represents a higher number of cells with the time of incubation (Fig. 2i). Cell passaging was performed to keep them viable and to grow for an extended period of time. Cells were passaged every 7-day interval till several passages. No phenotypic change in cells was observed from passage one to four (Fig. 2e-h). However, a number of cells remain almost the same after 7 days of each passage, because the cells entered the plateau phase on the seventh day (Fig. 2j).

\section{Study of surface marker expression to characterize MSCs}

Flow cytometric analysis has given significant information for MSC characterization. Higher expression of two positive cell surface markers, CD44 and CD90, was observed in the culture of undifferentiated cells, whereas CD45, a negative marker for MSCs, had negligible expression (Fig. 3a). From the quantitative data, we found $85.3 \%$ positive expression for CD44 and 78.3\% positive expression for CD90 (Fig. 3b). RTPCR analysis revealed that the markers CD73 and CD105 

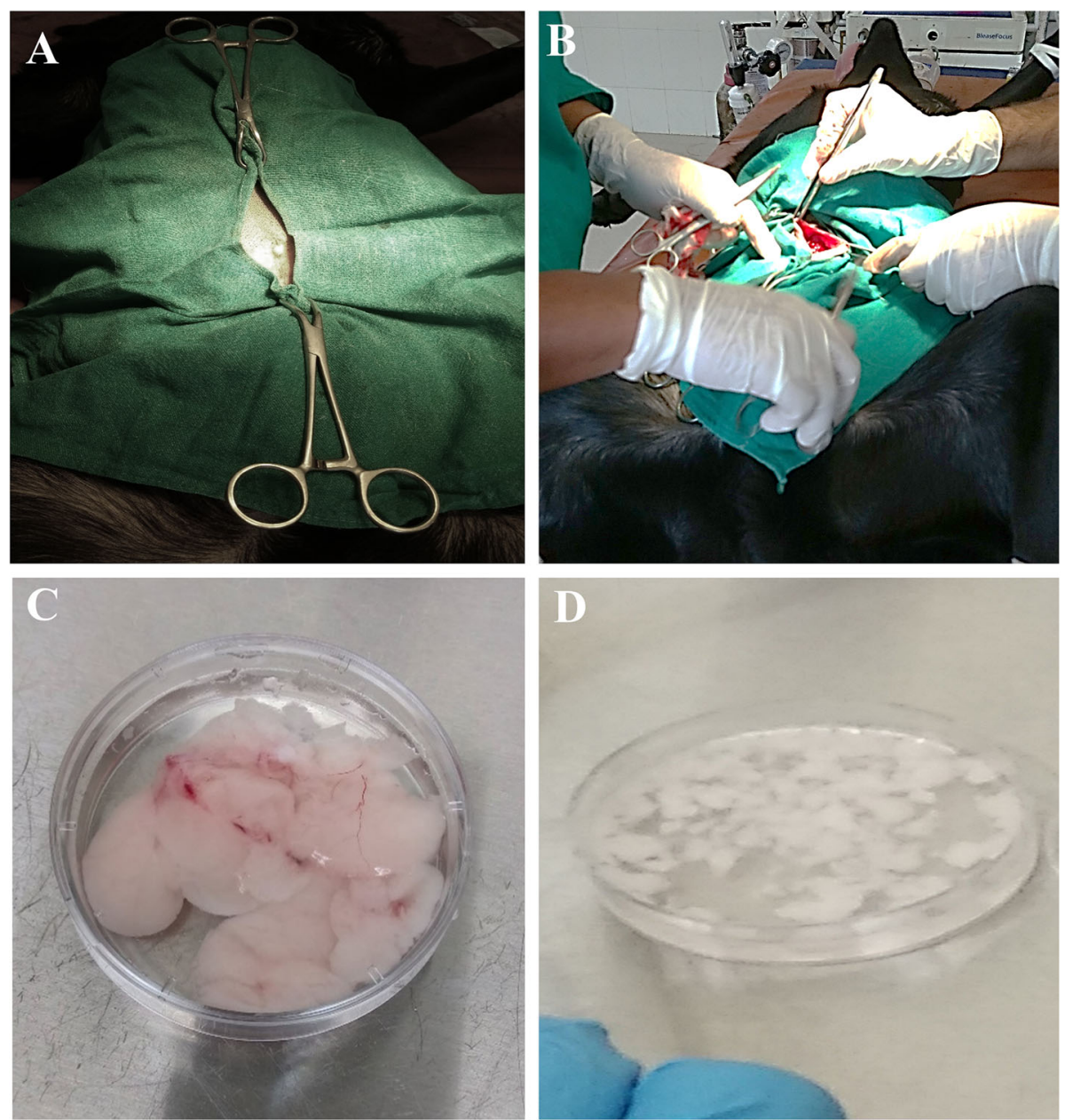

Fig. 1 Collection and processing of the canine adipose tissue. a Preparation of animal for tissue collection. $\mathbf{b}$ Incision in the abdomen for harvesting the adipose tissue under sterile condition. c Placement of the collected adipose tissue in sterile Petri plate in PBS. $\mathbf{d}$ Mincing of the adipose tissue for MSC primary culture

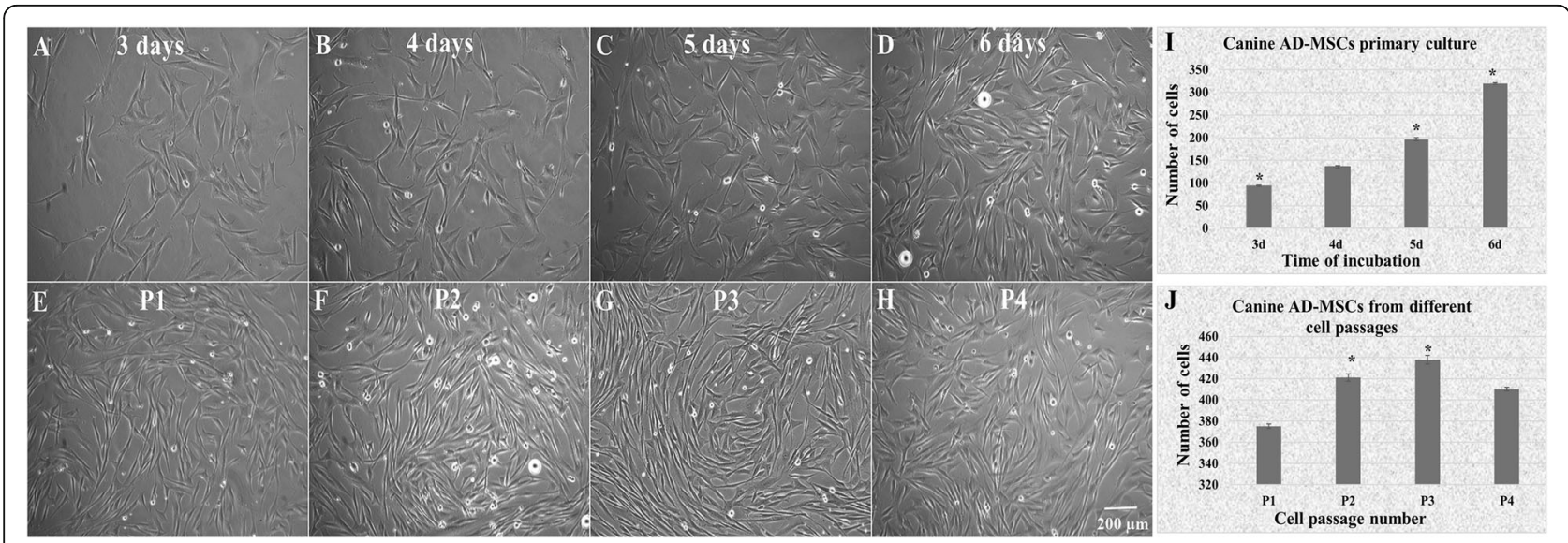

Fig. 2 Canine adipose tissue-derived primary culture. a-d Cells from passage zero were captured at days 3, 4, 5, and 6. e-h 70-80\% confluent monolayer cells from passage one to passage four. e Number of cells with the time of incubation. $\mathbf{j}$ Cells from different passages at the seventh day. The data represent means \pm SD. ${ }^{*} p<0.05$ was considered statistically significant 


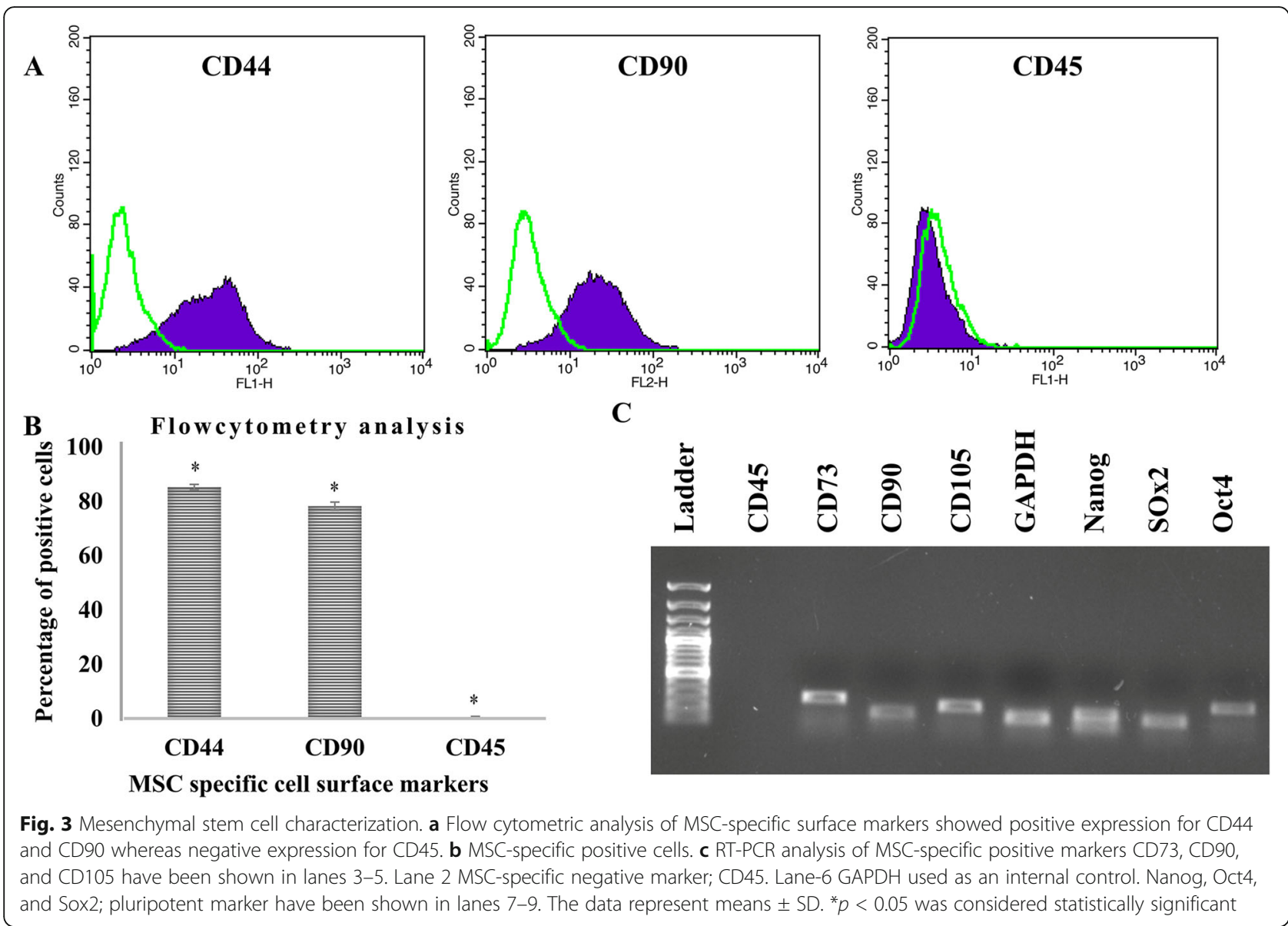

were expressed well than that of CD90, though it also has shown significant expression (Fig. 3c). Two pluripotency markers named Nanog and Sox2 expressed remarkably in the respective cells while the expression of another marker Oct4 is slightly lower in amount (Fig. 3c). These surface marker expression analyses through flow cytometric and RTPCR determined mesenchymal stem cell characterization.

\section{Calculation of population doubling time}

Monitoring and analyzing the quantity of cells are crucial for reliable optimization of growth rate. The proliferation of MSCs has entered the logarithmic growth phase from the first to the sixth day. According to the growth population, doubling time was determined using the formula $\mathrm{DT}=\mathrm{T} \times \log 2 / \log \left(\mathrm{N}_{\mathrm{t}} / \mathrm{N}_{\mathrm{o}}\right)$, till the fifth passage of MSCs. Up to the fourth passage, MSCs required about 18-24 h for a two-fold increment from the initial cell count. After passage four, it has taken $30 \pm 0.5 \mathrm{~h}$ for the doubling of cell population indicating the lowering of proliferation rate with the increasing passage number. This gives a significant parameter of cell growth required for further important in vitro experiments.

\section{Cell proliferation through MTT assay}

Breakdown of MTT reagent corresponds to the higher rate of cell proliferation. This chemical modulation is carried out by the mitochondrial succinate dehydrogenase enzyme of metabolically active cells. In this experiment, cell proliferation was measured in terms of optical density recorded in a microplate reader. Gradual passaging of well-grown primary cells corresponded with serial lowering of OD values, and it was inferred that cell proliferation reduced with an increase in the number of passages. The proliferation potential is higher in cells grown in DMEM-LG+ 20\% FBS than that of cells grown in DMEM-LG+ 10\% FBS suggesting a higher requirement of FBS in culture media as it contains a significant amount of growth factors essential for the cellular development (Fig. 4).

\section{Evaluation of in vitro cell migration through wound healing assay}

This experiment was done to evaluate in vitro cell migration. Cell migration is a fundamental process of the tissue development and driving factor for several morphogenetic events. Efficient migration of the 


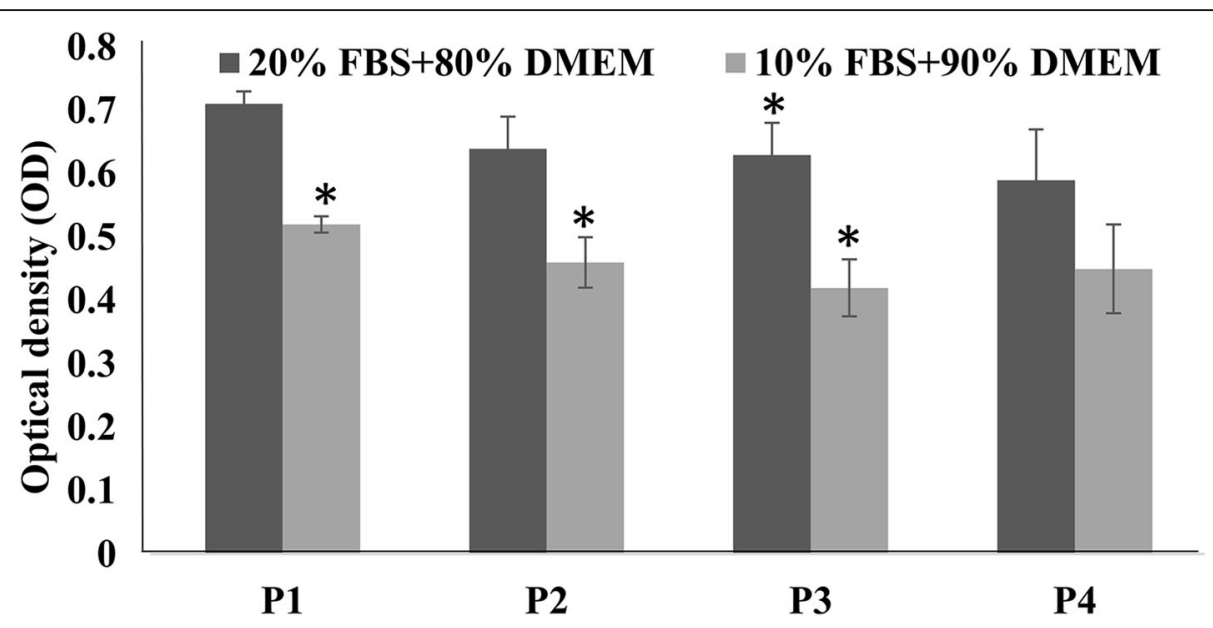

Fig. 4 Cell proliferation through MTT assay. The proliferative capacity of canine MSCs (passages P1-P4) under two different medium compositions ( $20 \% \mathrm{FBS}+80 \%$ DMDM-LG and 10\% FBS+90\% DMEM-LG) were evaluated after $72 \mathrm{~h}$ of incubation, and it was found that proliferation potential is higher in cells grown in 20\% FBS+DMEM-LG and also observed lowering OD values with increasing number of passages. The data represent means $\pm S D .{ }^{*} p<0.05$ was considered statistically significant

respective cells to the site of the wound is an important parameter for a successful regeneration process. Gradual filling of gaps created through scratching was represented in Fig. 5. The rate of cell migration calculated from the wound healing assay was $136.9 \pm 4.7$ $\mu \mathrm{m} / \mathrm{h}$. Bar diagram data represents the number of migrated cells with incubation period (Fig. 5d). This provides significant data to fulfill the goals of our present study regarding tissue damage restoration by means of the self-renewing ability of MSCs.
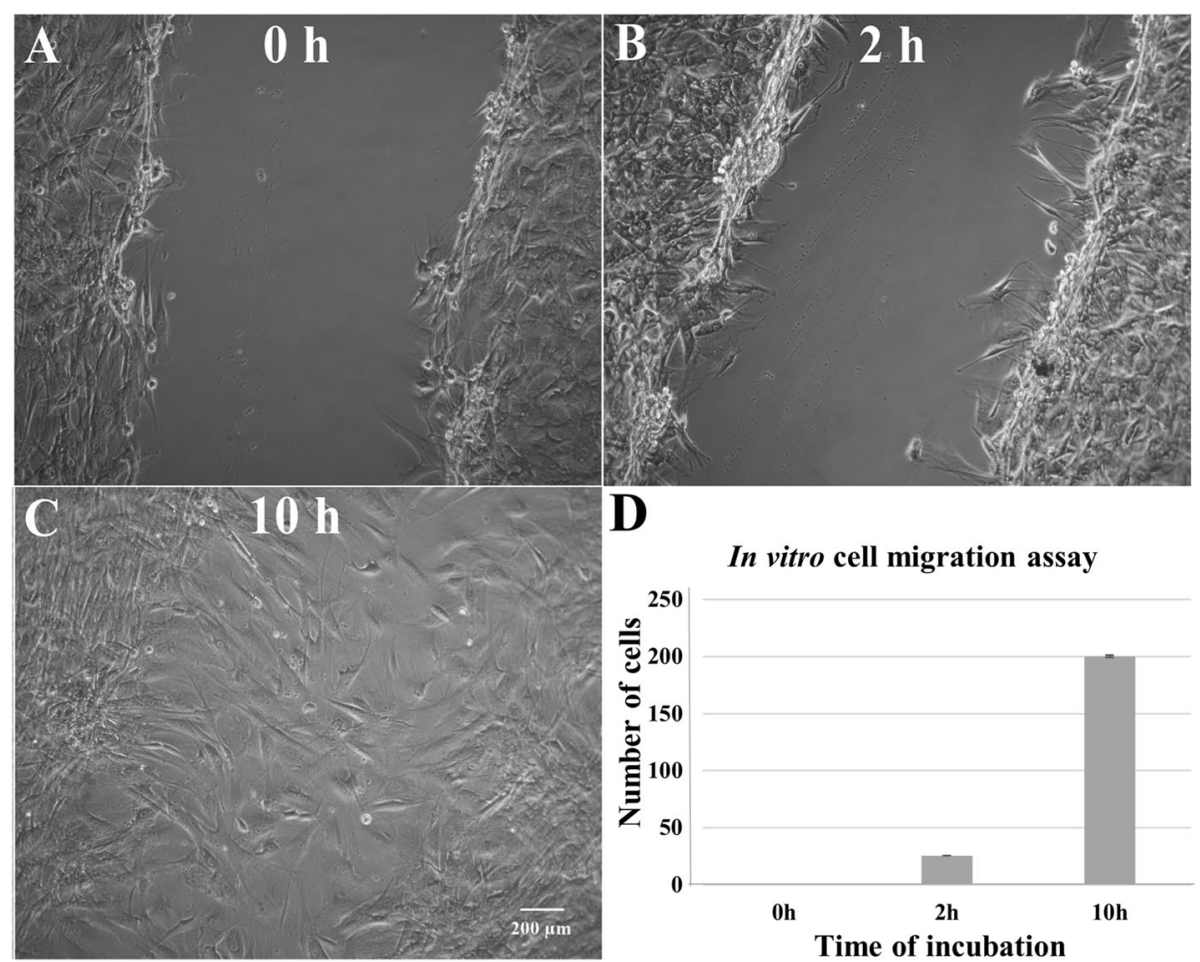

Fig. 5 In vitro cell migration through wound healing assay. Representative images of cell migration at 0, 2, and $10 \mathrm{~h}$ after scratch are shown in panel a-c. The average migration rate during $10 \mathrm{~h}$ in response to the scratch was calculated from three independent experiments. $\mathbf{d}$ The number of migrated cells with incubation time. The data represent means \pm SD. ${ }^{*} p<0.05$ was considered statistically significant 

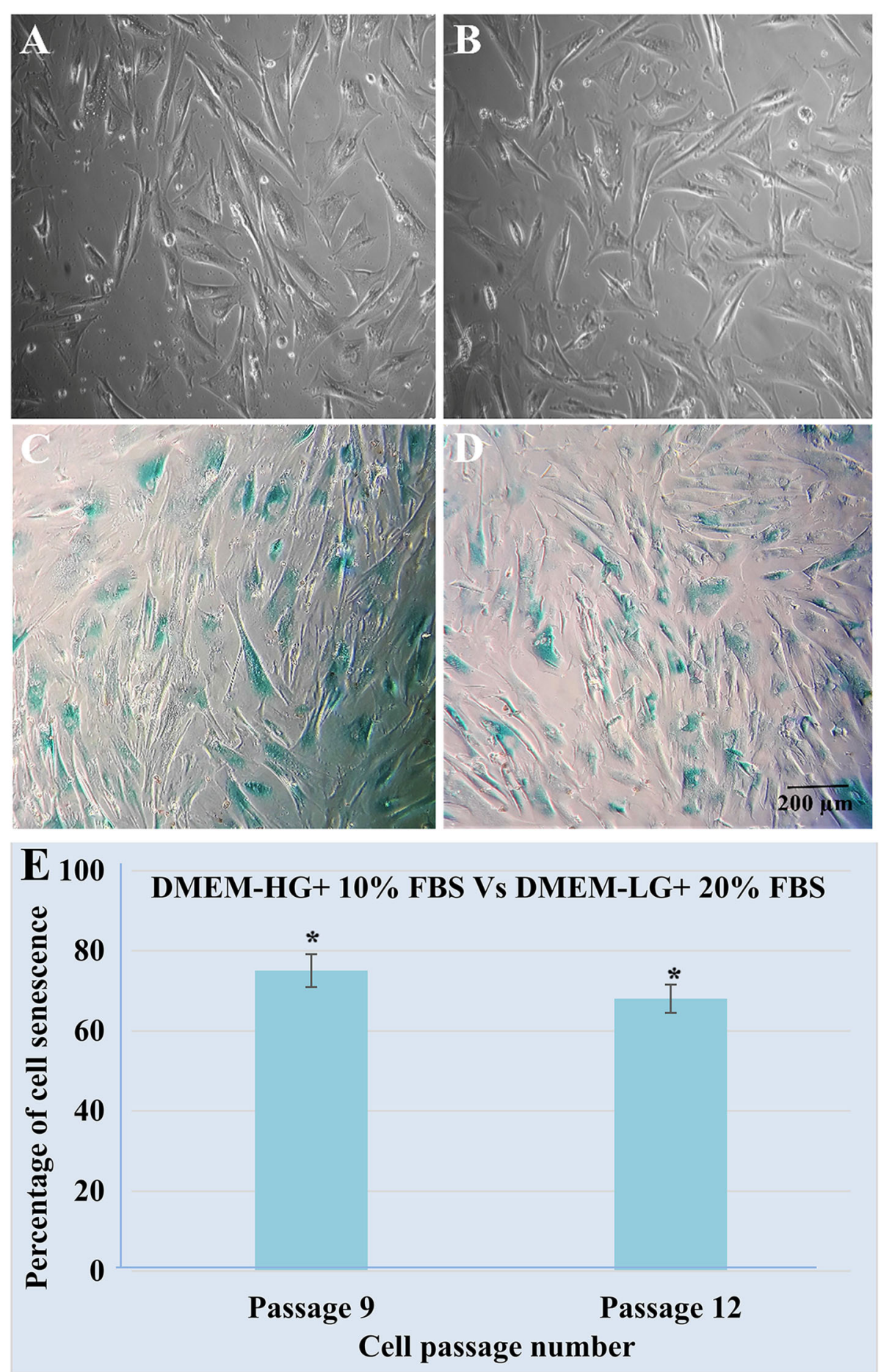

Fig. 6 Replicative senescence of canine MSCs. a Cells grown in DMEM-HG+ 10\% FBS reached senescence at passage 9. b Same phenomenon was observed at passage 12 when cells were grown in DMEM-LG+20\% FBS. Senescence cells were characterized by enlarged or flattened morphology and reduced proliferation capacity. Similarly, $\mathbf{c}$ d cell senescence in both culture medium as detected by senescence associated $\beta$-galactosidase activity. e Percentage of senescence cells at 9 th and 12 th passage. The data represent means \pm SD. ${ }^{*} p<0.05$ was considered statistically significant

Long-term in vitro proliferative leads to cell senescence In studying the senescence of MSCs, principally two types of media compositions (DMEM-HG+ 10\% FBS and DMEM-LG+ 20\% FBS) were used for several passages. Here, senescence was observed at the 9th passage when MSCs were grown in DMEM-HG+ 10\% FBS, 
whereas a similar phenomenon occurred at the 12th passage when cells grown in DMEM-LG+ 20\% FBS (Fig. 6a, b). Similarly, senescence was also assessed with a histochemical staining kit. A Bluish-green coloration of cells after $24 \mathrm{~h}$ of staining was observed, and this represents cellular $\beta$-galactosidase activity, a typical sign of senescence (Fig. 6c, d). We also found that the percentage of senescence cells was higher at the 9th passage (medium DMEM-HG+ 10\% FBS) as compared to the 12th passage (medium DMEM-LG+ 20\% FBS) (Fig. 6e). This result also highlighted the greater requirement of FBS along with a small amount of glucose for the delay of senescence

\section{In vitro induction of trilineage differentiation Osteogenesis}

Regular observation on the cell culture of osteogenic induction has given remarkable information about the gradual changes in respective cells. Distinguishable morphological changes are presented here based on 3, 7, 14, and $21 \mathrm{~d}$ of observation. Very small polygonal-shaped, crystalline structures were found in the experimental set during microscopic observation (Fig. $7 \mathrm{a}-\mathrm{d}$ ) and those were not seen in normal undifferentiated cells (Fig. 7e). The number of calcified crystalline structures increases with time. However, after 3 days of incubation, there were no such structures and they started appearing from day 7 (Fig. 7g). Deposited crystals of calcium compounds in the extracellular matrix were detected through the alizarin red S staining which caused the reddish-brown coloration of those calcified bodies (Fig. 7f).

RT-PCR data have given an authentic proof of collagen I gene expression in the cells of a 21-day-old culture. Another non-collagenous extracellular matrix protein of the bone referred to as osteopontin was expressed also in response to specific media composition for osteogenesis. Those two genes were not expressed prominently in undifferentiated cells as observed in the RT-PCR study (Fig. 7h). This has given a significant indication of successful osteogenic differentiation.

\section{Chondrogenesis}

During the serial observational period, the micromass formation in cultured cells was clearly seen after 11 days from chondrogenic induction. After 14 days, micromasses of larger size were observed in respective induced cells while no micromass formation was observed in the control set of undifferentiated cells (Fig. 8a-e). The size of micromasses was also represented with a bar diagram (Fig. 8g). Those micromasses were turned into
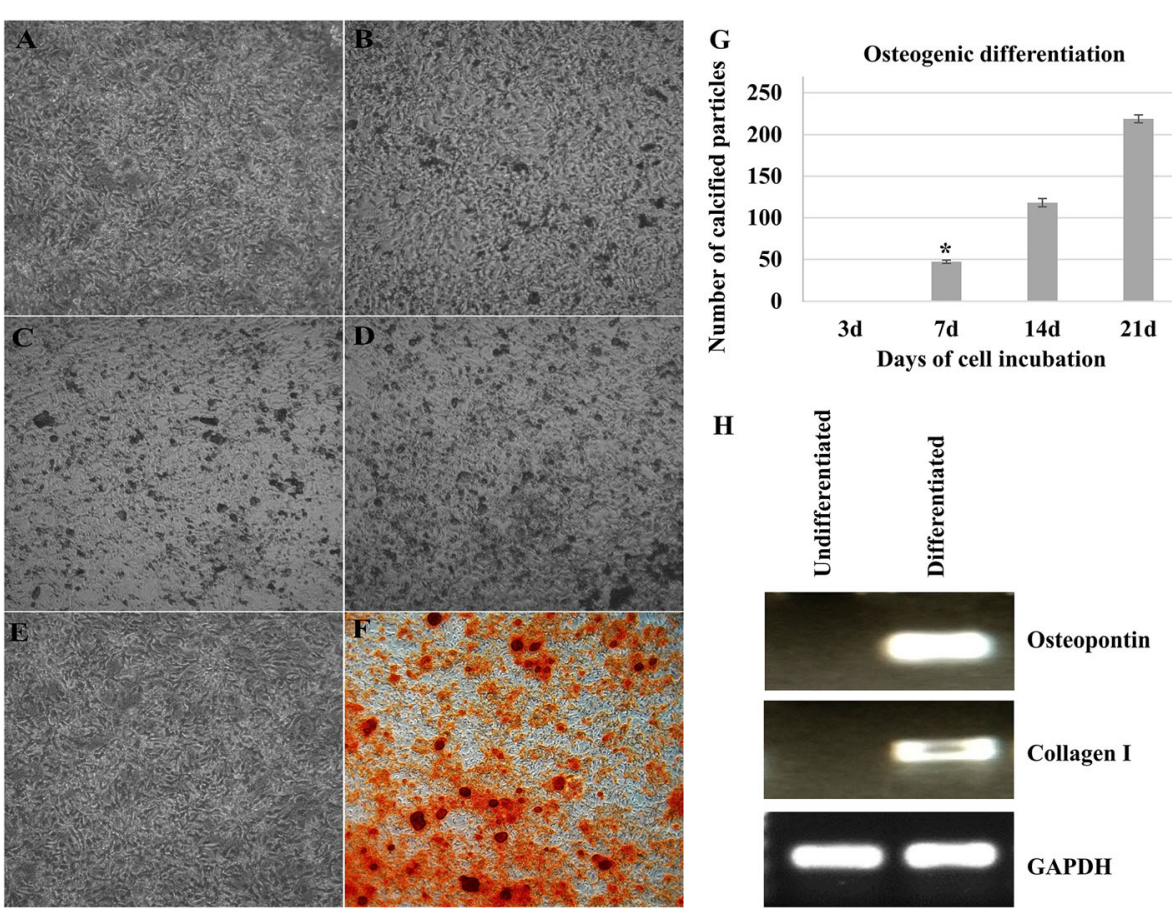

Fig. 7 Osteogenic differentiation of canine adipose tissue-derived MSCs. a-d Small black crystalline structures were observed at 3, 7, 14, and 21 days after osteogenic differentiation. $\mathbf{f}$ Deposited crystals were stained with alizarin red S stain which showed reddish-brown coloration. Negative control shown in panel $\mathbf{e}$ where no visible stain was observed. $\mathbf{g}$ The number of calcified crystalline structures with incubation time. $\mathbf{h}$ The characterization of osteocytes through RT-PCR. Expressions of osteopontin and collagen I, marker genes for osteocytes were compared with undifferentiated cells. We found positive expression for both the marker genes in differentiated cells whereas no expression was observed in undifferentiated cells. GAPDH was used as an internal control. The data represent means \pm SD. ${ }^{*} p<0.05$ was considered statistically significant 

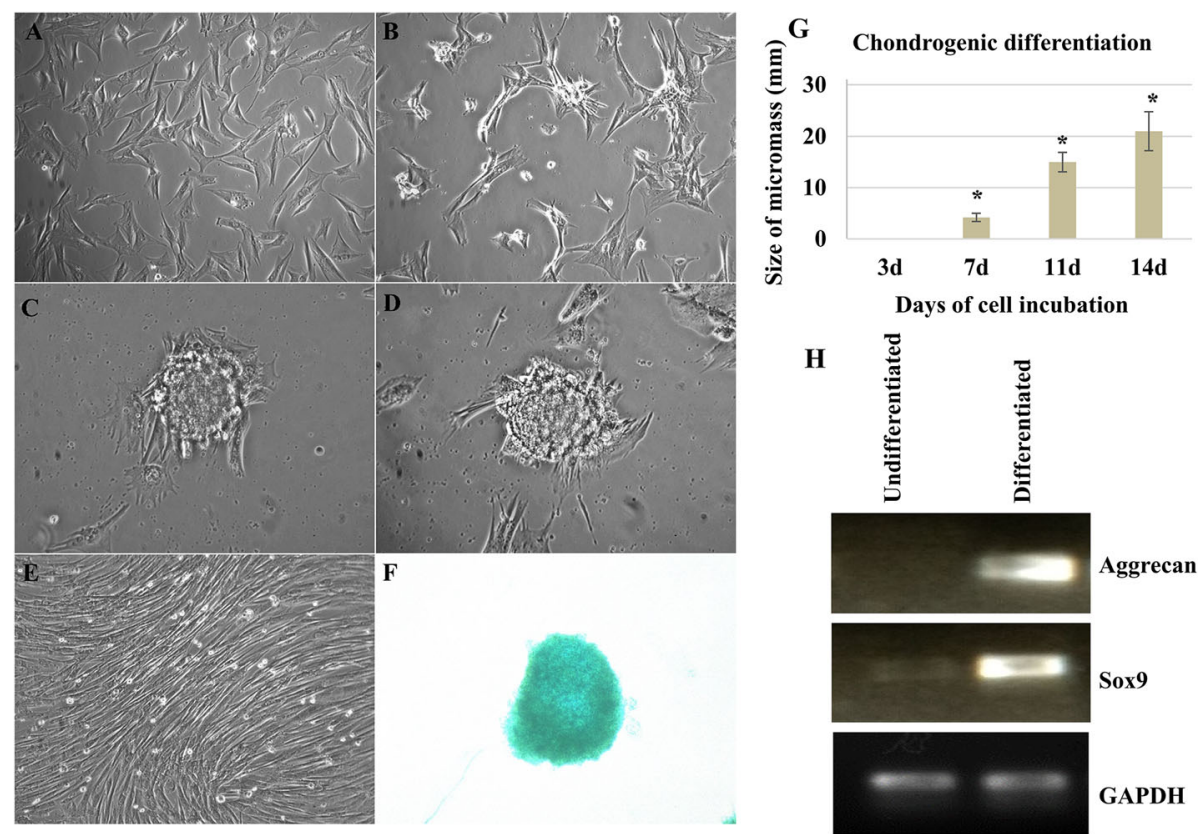

Fig. 8 Chondrogenic differentiation of canine adipose tissue-derived MSCs. a-d Morphological changes observed at 3, 7, 11, and 14 days after chondrogenic differentiation. $\mathbf{f}$ Alcian blue staining for aggrecan bodies during chondrogenic differentiation showed bluish-green coloration. $\mathbf{e}$ Negative control where no visible stain was observed. $\mathbf{g}$ Size of micromasses represented with bar diagram. $\mathbf{h}$ RT-PCR analysis for aggrecan and Sox9, marker genes for chondrocytes. Successful expression of both the marker genes was observed in chondrogenic differentiated cells. Sox9 expression was also observed in undifferentiated cells, although expression was quite low compared to chondrocyte-differentiated cells. GAPDH was used as loading control. The data represent means \pm SD. ${ }^{*} p<0.05$ was considered statistically significant

bluish-green after staining with Alcian blue (Fig. 8f) and that indicated the presence of sulphated proteoglycans such as aggrecan in the matrix of the cell.

Sox9 involved in regulating chondrogenesis and chondrocyte proliferation was expressed significantly as observed in the RT-PCR analysis. Similarly, higher expression of aggrecan was also observed in cells grown for chondrogenesis in comparison with the control ones (Fig. 8h). These recordable data confirmed the successful chondrogenesis in this in vitro experimental study.

\section{Adipogenesis}

Adipogenic differentiation is characterized by the presence of lipid droplets embedded in the cytoplasm of flat, large, and wide cells. The existence of a few glossy, spheroid lipid droplets was observed after 7 days of a cellular induction for adipocyte development. On the contrary, no such morphological changes were visible in case of undifferentiated cells. It is remarkable that a higher number of conspicuous larger-sized semi-liquid fat globules were seen after 14 and 21 days of adipogenic induction (Fig. 9a-e, g). Deep brown coloration of those lipid bodies observed through oil red $\mathrm{O}$ staining confirmed the occurrence of adipogenesis (Fig. 9f).

RT-PCR analysis revealed that leptin and FABP4, the two classic markers, expressed positively in the cells growing for adipogenic differentiation. Those adipogenic progenitors were not expressed considerably in undifferentiated cells (Fig. 9h). It is noteworthy here for drawing inference for effective adipogenic differentiation of cells.

\section{Discussion}

According to the International Society for Cellular Therapy, the major criteria for defining (MSCs) are stated as (a) plastic adherence; (b) expression of surface markers like CD44, CD73, CD90, and CD105 (positive markers); (c) absence of some surface markers such as CD34 and CD45 (negative markers); (d) multipotent differentiation potential of chondrocytes; osteocytes; and adipocytes under different standard conditions in vitro (Dominici et al., 2006).

In this study, it may be stated that the development of stem cell proper has been done in vitro as the cells have fulfilled the criteria mentioned above. The adipose tissue collected from the veterinary clinic was transported to the laboratory for stem cell culture (Fig. 1). The elongated, spindle-shaped, fibroblast-like appearance of cells was observed after $72 \mathrm{~h}$ of initial culture (Fig. 2). These are the specialized phenotypic features of mesenchymal stem cells (Haasters et al., 2009). Expression of cell surface markers like CD44, CD73, CD90, and CD105 observed through RT-PCR results has confirmed the typical MSC generation from canine white adipose tissue. None of the two selected negative markers namely 

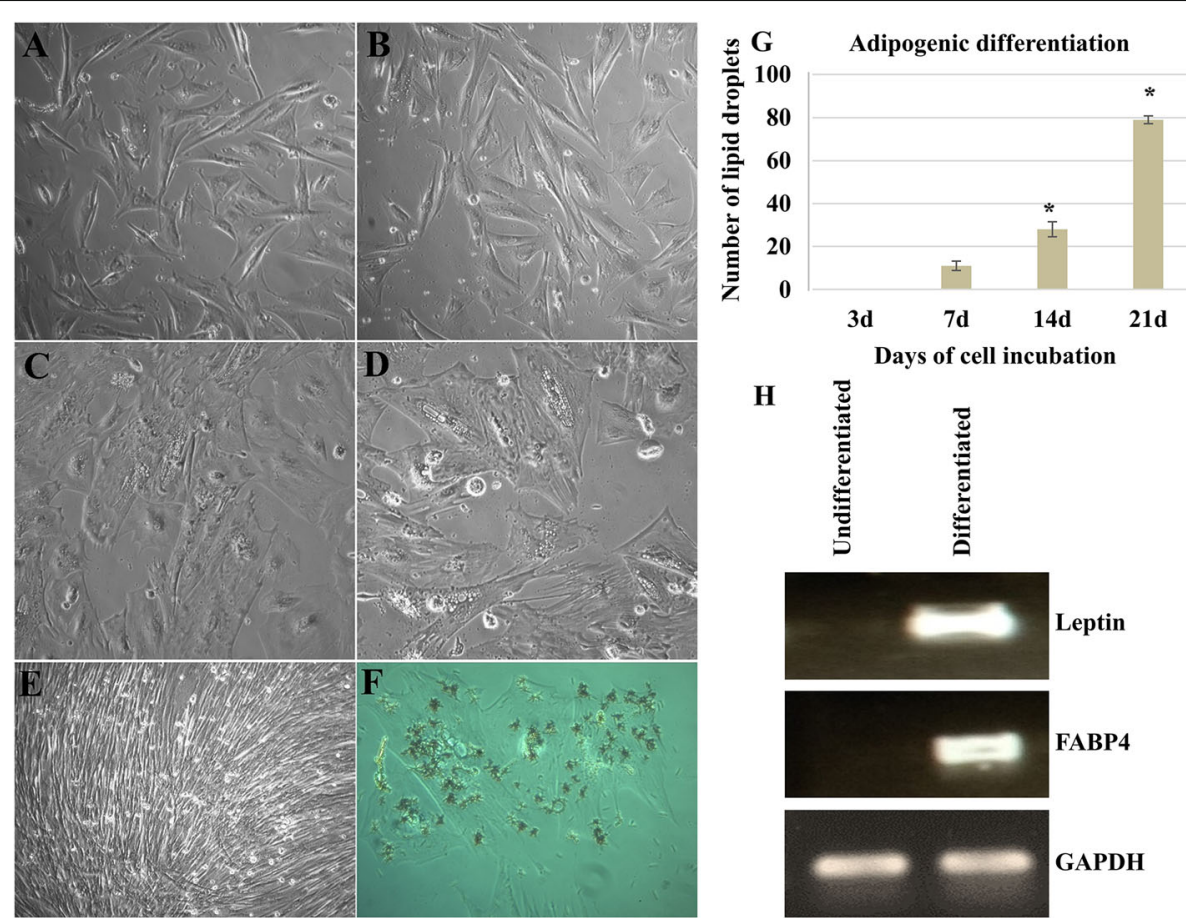

Fig. 9 Adipogenic differentiation of canine adipose tissue-derived MSCs. a-d Morphological changes were observed after 7, 14, 17, and 21 days of adipogenic differentiation. Formation of lipid droplet was observed in differentiated cells during this period. $\mathbf{f}$ Lipid droplets were stained with oil $O$ red stain and e used as a negative control. $\mathbf{g}$ Number of lipid droplets with incubation period. $\mathbf{h}$ RT-PCR analysis for leptin and FABP4, marker genes for adipocytes. We observed much higher expression of leptin in differentiated cells, whereas FABP4 expression was observed only in adipogenic differentiated cells. GAPDH was used as loading control. The data represent means \pm SD. ${ }^{*} p<0.05$ was considered statistically significant

CD34 and CD45 were expressed and complemented the corroboration of the genesis of MSCs (Fig. 3c). In addition, higher expression of CD44 and CD90 obtained from flow cytometric analysis was also the indication of common characteristics of MSCs in this in vitro experimental study (Fig. 3a, b). Those outcomes have given supportive evidences for the agreement with the previous reports (Mercati et al., 2009; Yaneselli et al., 2018).

Expression of three pluripotency markers such as Oct4, Nanog, and Sox2 in our present study (Fig. 3c) has ensured the ability of the respective stem cells to undergo self-renewal, and those may give rise to all types of cells of a living body depending on the types of induction. Stemness of those adipose tissue-derived cells can be suggested through the detection of the abovementioned pluripotency-associated transcription factors (Neupane et al., 2008). Normally, the gene expression level of those pluripotent markers make a correlation with population doubling of cells as cell aging starts with a longer time requirement for the doubling of cell numbers together with gradual reduction of pluripotency (Piccinato, Sertie, Torres, Ferretti, \& Antonioli, 2015).

It was reported that the beneficial effects of MSC transplantation for the restoration of cell deficit caused by tissue injury are mainly based on their rate of survival and capacity of proliferation $(\mathrm{Hu}$, Zhang, Gu, \& Guan,
2012). The self-proliferative capability of MSCs is the key factor for their sustainable growth and maintenance regarding therapeutic uses as they eventually undergo replicative senescence after a longer period of normal culture. In our present study, cultured cells underwent senescence at passage twelve in case of cells grown in medium containing DMEM-LG+ 20\% FBS content whereas signs of senescence were detected at passage nine in the cells grown in the medium with DMEMHG+ 10\% FBS (Fig. 6). This has shown similarity with the report of Yang, Shen, Reece, Chen, and Yanga (2016) where cells maintained their pluripotency and ability of differentiation in low-glucose medium, but both of those were considerably impaired by the high-glucose content of the growing medium. A higher amount of FBS in a culture medium may also be the effective factor for higher cell proliferation as FBS contains a significant amount of growth factors essential for the cellular development, and its protein components play a vital role in modulating the metabolic activity of the cells (Fig. 4) (Deorosan, Byron, and Nauman (2011). Here, the combinatorial effect of low-glucose and high-FBS content may be the possible reason for the enhanced rate of cell proliferation as well.

Cell proliferation makes a direct relationship with wound healing which determines the rate of cell 
migration at the site of injury. It is a complex restorative process requiring a functional coordination among cells, growth factors, and extracellular matrix proteins (Himal et al., 2017). Through the self-renewing capability, MSCs mediate this repair mechanism by involving other cells and the secretion of growth factor plus matrix proteins (Yoo, Maxson, Danilkovitch-Miagkova, LeRoux, \& Lopez, 2012). Statement of a clinical update also indicated that the secretion of cytokines and growth factors by MSCs eventually leads to epithelization through this process of regeneration (Mester et al., 2018). Our present result of the experiment (Fig. 5) conforms with previous reports where this unique restoration capacity of MSCs was mentioned (Mester et al., 2018; Yoo et al., 2012). It is a mini representative of studying the regenerative ability of MSCs before in vivo application using a suitable animal model.

Structurally, bone is a highly complex, specialized type of a connective tissue whose organic matrix is composed mainly of collagen I fibers (approx. 95\%) and numerous non-collagenous proteins (about 5\%). The matrix is strengthened by the deposition of calcified crystals embedded in cells, i.e., osteocytes which participate in the organization and maintenance of the bones (Barrère, van Blitterswijk, \& de Groot, 2006). In our present study, calcium deposition has provided a proof for osteogenic differentiation along with collagen 1 expression (Fig. $7 \mathrm{a}-\mathrm{g}$ ) which is normally found in the extracellular matrix of bones as the obtained result corresponded to the analytical studies of Matsuoka et al. (1999) and Buchwald, Kozielski, and Szybowicz (2012). Another osteocytespecific marker, osteopontin, was also expressed in the respective set of our study (Fig. 7h). This result has supported the view of Morinobu et al. (2003).

Chondrocytes consist of collagen and proteoglycan, produce, and maintain the matrix of the cartilage tissue. Aggrecan mediates chondrocyte-chondrocyte and chondrocyte-matrix interaction by using hyaluronan inside the cartilage tissue (Kiani, Chen, Wu, Yee, \& Yang, 2002). Our RT-PCR data have shown significant expression of aggrecan during chondrogenic differentiation (Fig. 8). However, Mwale, Stachura, Roughley, and Antoniou (2006) disagreed that aggrecan is a good marker for chondrogenesis from human bone marrow-derived MSCs. This type of disparity may appear from the difference in tissue source along with the species variation. On the contrary, Xu et al. (2008) found a peak level of aggrecan expression during chondrogenic differentiation of human MSCs. Neupane et al. (2008) reported the higher expression of aggrecan during chondrogenesis from canine ADSCs. Our experimental result conforms with these reports. Sox9, a crucial element for cartilage development, was expressed significantly in cells grown in a chondrogenic differentiation medium. Therefore, sox9 has presented itself as an important component in successful chondrogenic induction from mesenchymal stem cells. In this regard, our in vitro study (Fig. 8) has shown similarity with the report of Leung et al. (2011).

Leptin is an adipose tissue-derived protein that participates in a wide range of physiological functions like reproduction, thyroid function, bone density, the immune biology (Wrann \& Rosen, 2012). The primary site of leptin production is the adipocyte, although it is expressed in some other tissues in a lower amount (Harris, 2014). Higher expression of leptin mRNAs indicated the remarkable adipogenic differentiation from undifferentiated MSCs in this study (Fig. 9). On account of being a marker of the population of adipocyte progenitor, FABP4 expression in cells has become one of the typical features of adipogenic differentiation (Shan, Liu, \& Kuang, 2013). Neupane et al. (2008) and Vieira et al. (2010) also have demonstrated the expression of leptin and FABP4 during adipogenic differentiation observing in their own experimental studies. We have get similarity with those previous reports in our study. Reversible cellular differentiation ability was observed in this study through this adipogenic differentiation from pluripotent MSCs derived from canine white adipose tissue.

\section{Conclusion}

Clinical investigation has approved the remarkable regenerative potentials of stem cells despite limited success in the understanding of their in vivo function (Prentice, 2019). The information obtained from this study should be given importance for rigorous analysis of the basic biology of the canine mesenchymal stem cells regarding their clinical application. In addition, preservation of cultured osteocytes and chondrocytes with proper maintenance might be utilized in bone fracture restoration through a regenerative therapeutic approach. Application of those cells to the specific target through a suitable delivery system in combination with available drug regimen may give a better treatment option for some incurable orthopedic injuries in the very near future.

\section{Abbreviations \\ SVF: Stromal vascular fraction; AD-MSCs: Adipose tissue-derived mesenchy- mal stem cells; DPBS: Dulbecco's phosphate-buffered saline; DMEM-HG/ LG: Dulbecco's modified Eagle's medium-high glucose/low glucose; FITC: Fluorescein isothiocyanate; PE: Phycoerythrin; RT-PCR: Reverse transcription-polymerase chain reaction; MTT: [3-(4,5-Dimethylthiazol-2-yl)-2,5- diphenyltetrazolium bromide]; WBUAFS: West Bengal University of Animal and Fishery Sciences}

\section{Acknowledgements}

AM would like to acknowledge the Principal, Mrinalini Datta Mahavidyapith, Birati, Kolkata 700051, India, for encouragement and necessary support. All the authors are grateful to the university authority for providing all sorts of assistance to carry out the research work. 


\section{Authors' contributions}

AM analyzed and interpreted all the data, conducted all lab work, and had a major contribution. AKJ prepared manuscript and assisted in cell culture. DB conducted cell culture and maintenance work, and SKG guided throughout the study and conducted surgical work. The authors read and approved the final manuscript.

\section{Funding}

This research work was funded by ICMR, GOI vide sanction letter no. 90/20/ 2012/SCRT (TF)/BMS. Dr. Anirban Mandal received fellowship award from the same funding agency.

\section{Availability of data and materials}

All the data and materials used to reach the conclusion of this study are available from the corresponding authors on reasonable request.

\section{Declarations}

\section{Ethics approval and consent to participate}

The authors have obtained ethical approval vide reference number F.No. 25/ 15/2018-CPCSEA, dated 14/09/2018 from the concerning authority (Committee for the purpose of control and supervision of experiments on animals, Government of India) to isolate, expand, and apply AD-MSCs in canine osteoarthritic patients. Total 5 donor dogs were selected for collection of adipose tissue based on the history of satisfactory health status, no recent medication, proper vaccination, owners' harmony, and informed consent were written. All the experiments were conducted after receiving the approval from CPCSEA, Government of India.

\section{Consent for publication}

Not applicable

\section{Competing interests}

The authors declare that they have no competing interests.

\section{Author details}

Stem Cell Laboratory, Department of Veterinary Clinical Complex, West Bengal University of Animal and Fishery Sciences, Kolkata 700037, India. ${ }^{2}$ Department of Microbiology, Mrinalini Datta Mahavidyapith, Birati, Kolkata 700051, India. ${ }^{3}$ Department of Veterinary Gynaecology and Obstetrics, West Bengal University of Animal and Fishery Sciences, Kolkata 700037, India. ${ }^{4}$ Department of Life Science, Presidency University, Kolkata 700073, India.

\section{Received: 7 July 2020 Accepted: 3 May 2021}

Published online: 22 May 2021

\section{References}

Barrère, F., van Blitterswijk, C. A., \& de Groot, K. (2006). Bone regeneration: molecular and cellular interactions with calcium phosphate ceramics. International Journal of Nanomedicine, 1(3), 317-332.

Brandalise, V., et al. (2010). Isolation, characterization, and differentiation potential of canine adipose-derived stem cells. Cell Transplantation, 19(3), 279-289.

Buchwald, T., Kozielski, M., \& Szybowicz, M. (2012). Determination of collagen fibers arrangement in bone tissue by using transformations of raman spectra maps. Spectroscopy: An International Journal, 27(2), 107-117. https://doi.org/1 0.1155/2012/261487.

Chagastelles, P. C., \& Nardi, N. B. (2011). Biology of stem cells : an overview. Kidney International Suppliment, 1(3), 63-67. https://doi.org/10.1038/kisup.2 011.15 .

Chen, J., Zhou, L., \& Pan, S. (2014). A brief review of recent advances in stem cell biology. Neural Regeneration Research, 9(7), 7-10.

Deorosan, Byron, \& Nauman, E. A. (2011). The role of glucose, serum, and threedimensional cell culture on the metabolism of bone marrow-derived mesenchymal stem cells. Stem Cells International, 2011, 1-13. https://doi.org/1 0.4061/2011/429187.

Dominici, M., le Blanc, K., Mueller, I., Slaper-Cortenbach, I., Marini, F. C., Krause, D. S., ... Horwitz, E. M. (2006). Minimal criteria for defining multipotent mesenchymal stromal cells. The International Society for Cellular Therapy position statement. Cytotherapy, 8(4), 315-317. https://doi.org/10.1080/14 653240600855905 .
Facchin, F., Bianconi, E., Canaider, S., Basoli, V., Biava, P. M., \& Ventura, C. (2018). Tissue regeneration without stem cell transplantation: self-healing potential from ancestral chemistry and physical energies. Stem Cells International, 2018, 1-9. https://doi.org/10.1155/2018/7412035.

Greenwood, S. K., Hill, R. B., Sun, J. T., Armstrong, M. J., Johnson, T. E., Gara, J. P., \& Galloway, S. M. (2004). Population doubling : a simple and more accurate estimation of cell growth suppression in the in vitro assay for chromosomal aberrations that reduces irrelevant positive results. Environtal and Molecular Mutagenesis, 43(1), 36-44. https://doi.org/10.1002/em.10207.

Haasters, F., Prall, W. C., Anz, D., Bourquin, C., Pautke, C., Endres, S., ... Schieker, M. (2009). Morphological and immunocytochemical characteristics indicate the yield of early progenitors and represent a quality control for human mesenchymal stem cell culturing. Journal of Anatomy, 214(5), 759-767. https://doi.org/10.1111/j.1469-7580.2009.01065.x.

Harris, R. (2014). Direct and indirect effects of leptin on adipocyte metabolism. Biochimica et Biophysica Acta (BBA) - Molecular Basis of Disease, 1842(3), 414423. https://doi.org/10.1016/j.bbadis.2013.05.009.

Himal, l., Goyal, U., \& Ta, M. (2017). Evaluating Wharton's jelly-derived mesenchymal stem cell's survival, migration, and expression of wound repair markers under conditions of ischemia-like stress. Stem Cells International, 2017, 1-13. https://doi.org/10.1155/2017/5259849.

Hu, N., Zhang, Y. Y., Gu, H. W., \& Guan, H. J. (2012). Effects of bone marrow mesenchymal stem cells on cell proliferation and growth factor expression of limbal epithelial cells in vitro. Ophthalmic Research, 48(2), 82-88. https://doi. org/10.1159/000331006.

Kiani, C. H., Chen, L. I., Wu, Y. A. O. J. I., Yee, A. L. J., \& Yang, B. U. B. (2002). Structure and function of aggrecan. Cell Research, 12(1), 19-32. https://doi. org/10.1038/sj.cr.7290106.

Kim, E.-H. (2014). Current applications of adipose-derived stem cells and their future perspectives. World Journal of Stem Cells, 6(1), 65-68. https://doi.org/1 0.4252/wjsc.v6.i1.65.

King, R. S., \& Newmark, P. A. (2012). The cell biology of regeneration. Journal of Cell Biology, 196(5), 553-562. https://doi.org/10.1083/jcb.201105099.

Kriston-Pál, É., et al. (2017). Characterization and therapeutic application of canine adipose mesenchymal stem cells to treat elbow osteoarthritis. Canadian Journal of Veterinary Research, 81(1), 73-78.

Leung, V. Y. L., et al. (2011). SOX9 governs differentiation stage-specific gene expression in growth plate chondrocytes via direct concomitant transactivation and repression. PLoS Genetics, 7(11), 1-16.

Matsuoka, H., Akiyama, H., Okada, Y., Ito, H., Shigeno, C., Konishi, J., ... Nakamura, T. (1999). In vitro analysis of the stimulation of bone formation by highly bioactive apatite- and wollastonite-containing glass-ceramic: released calcium ions promote osteogenic differentiation in osteoblastic ROS17/2.8 cells. Journal of Biomedical Materials Research, 47(2), 176-188. https://doi. org/10.1002/(SICI) 1097-4636(199911)47:2<176::AID-JBM7>3.0.CO;2-Z.

Mercati, F., et al. (2009). Expression of mesenchymal stem cell marker CD90 on dermal sheath cells of the anagen hair follicle in canine species. European Journal of Histochemistry, 53(3), 159-166.

Mester, A., Opincariu, D., Benedek, I., \& Benedek, I. (2018). Stem cell therapy in wound healing. Journal of Interdisciplinary Medicine, 2(s4), 20-24.

Morinobu, M., et al. (2003). Osteopontin expression in osteoblasts and osteocytes during bone formation under mechanical stress in the calvarial suture in vivo. Journal of Bone and Mineral Research, 18(9), 1706-1715.

Mosmann, T. (1983). Rapid colorimetric assay for cellular growth and survival: application to proliferation and cytotoxicity assays. Journal of Immunological Methods, 65(1-2), 55-63. https://doi.org/10.1016/0022-1759(83)90303-4.

Mwale, F., Stachura, D., Roughley, P., \& Antoniou, J. (2006). Limitations of using aggrecan and type $X$ collagen as markers of chondrogenesis in mesenchymal stem cell differentiation. Journal of Orthopaedic Research, 24(8), 1791-1798.

Neupane, M., Kiupel, M., \& Yuzbasiyan-gurkan, V. (2008). Isolation and characterization of canine adipose-derived mesenchymal stem cells. Tissue Engineering, 14(6), 1007-1015. https://doi.org/10.1089/ten.tea.2007.0207.

Ogawa, R., Mizuno, H., Watanabe, A., Migita, M., Shimada, T., \& Hyakusoku, H. (2004). Osteogenic and chondrogenic differentiation by adipose-derived stem cells harvested from GFP transgenic mice. Biochemical and Biophysical Research Communications, 313(4), 871-877. https://doi.org/10.1016/j.bbrc.2 003.12.017.

Özen, A., Gül Sancak, l., Ceylan, A., \& Özgenç, O. (2016). Isolation of adipose tissue-derived stem cells. Turkish Journal of Veterinary and Animal Sciences, 40, 137-141. https://doi.org/10.3906/vet-1505-54. 
Piccinato, C. A., Sertie, A. L., Torres, N., Ferretti, M., \& Antonioli, E. (2015). High OCT4 and low p16 INK4A expressions determine in vitro lifespan of mesenchymal stem cells. Stem Cells International, 2015, 1-12. https://doi.org/1 $0.1155 / 2015 / 369828$.

Prentice, D. A. (2019). Adult stem cells successful standard for regenerative medicine. Circulation Research, 124(6), 837-839.

Shan, T., Liu, W., \& Kuang, S. (2013). Fatty acid binding protein 4 expression marks a population of adipocyte progenitors in white and brown adipose tissues. The FASEB Journal, 27(1), 277-287. https://doi.org/10.1096/fj.12-211516.

Tan, K., et al. (2019). CD73 Expression on mesenchymal stem cells dictates the reparative properties via its anti-inflammatory activity. Stem Cells International, 2019, 1-12.

Van Deursen, J. M. (2014). The role of senescent cells in ageing. Nature, 509(7501), 439-446. https://doi.org/10.1038/nature13193.

Vieira, N. M., et al. (2010). Isolation, characterization, and differentiation potential of canine adipose-derived stem cells. Cell Transplantation, 19(3), 279-289.

Wrann, C. D., \& Rosen, E. D. (2012). New insights into adipocyte-specific leptin gene expression. Adipocyte, 1(3), 168-172. https://doi.org/10.4161/adip.20574.

Xu, J., Wang, W., Ludeman, M., Cheng, K., Hayami, T., Lotz, J. C., \& Kapila, S. (2008). Chondrogenic differentiation of human mesenchymal stem cells in threedimensional alginate gels. Tissue Engineering, 14(5), 667-680. https://doi.org/1 0.1089/tea.2007.0272.

Yaneselli, K. M., et al. (2018). Comparison of the characteristics of canine adipose tissue-derived mesenchymal stem cells extracted from different sites and at different passage numbers. Journal of Veterinary Science, 19(1), 13-20.

Yang, P., Shen, W.-b., Reece, E. A., Chen, X., \& Yanga, P. (2016). High glucose suppresses embryonic stem cell differentiation into neural lineage cells. Biochemical and Biophysical Research Communications, 472(2), 306-312. https://doi.org/10.1016/j.bbrc.2016.02.117.

Yoo, D., Maxson, S., Danilkovitch-Miagkova, A., LeRoux, M. A., \& Lopez, E. A. (2012), Concise review: role of mesenchymal stem cells in wound repair. Stem Cells Translational Medicine, 1(2), 142-149.

Zajdel, A., Kałucka, M., Kokoszka-mikołaj, E., \& Wilczok, A. (2017). Osteogenic differentiation of human mesenchymal stem cells from adipose tissue and Wharton's jelly of the umbilical cord. Acta Biochimica Polonica, 64(2), 365369. https://doi.org/10.18388/abp.2016_1488.

\section{Publisher's Note}

Springer Nature remains neutral with regard to jurisdictional claims in published maps and institutional affiliations.

\section{Submit your manuscript to a SpringerOpen ${ }^{\circ}$ journal and benefit from:}

- Convenient online submission

- Rigorous peer review

- Open access: articles freely available online

High visibility within the field

- Retaining the copyright to your article

Submit your next manuscript at $\boldsymbol{\nabla}$ springeropen.com 